\title{
Adoption of biodegradable mulching films in agriculture: is there a negative prejudice towards materials derived from organic wastes?
}

\author{
Myriam Anna Scaringelli, ${ }^{1}$ Giacomo Giannoccaro, ${ }^{1,2}$ Maurizio Prosperi,, \\ Antonio Lopolito ${ }^{1,2}$ \\ ${ }^{1}$ Department of Agriculture, Food and Environment, University of Foggia; ${ }^{2}$ STAR ${ }^{*}$ AgroEnergy \\ Group, University of Foggia, Italy
}

\begin{abstract}
During the last years ongoing research has moved towards the valorisation of organic waste by the identification of possible products with a good market perspective. In this paper we consider the possibility of using the organic fraction of municipal waste to produce biodegradable mulching films for agricultural purposes.

The aim of this research was to estimate the potential demand of horticultural farms located in the province of Foggia (Italy) for biodegradable films derived from organic waste. We carried out a survey of 107 producers in the area. Findings showed that the adoption of the innovative films does not depend on the nature of the raw material used and that the willingness to pay for such films is higher with respect to the price of similar products already available in the market. In addition, farmers' preferences towards mulching films' attributes
\end{abstract}

Correspondence: Myriam Anna Scaringelli, Department of Agriculture, Food and Environment (SAFE), University of Foggia, via Napoli 25, 71122 Foggia, Italy.

E-mail: myriam.scaringelli@unifg.it

Key words: Innovation; biodegradable mulching film; farmers' adoption behaviour; willingness to pay.

Acknowledgements: STAR*AgroEnergy Research Group is a scientific network promoted by the University of Foggia within the European project STAR*AgroEnergy (Strategic \& Technological Advancement in Research on AgroEnergy). The project is funded by the European Commission, Directorate-General for Research \& Innovation, SP4 - Capacities, Coordination and Support Action, Seventh Framework Programme (FP7), Regpot 2011-1. Grant Agreement No. 286269. Giacomo Giannoccaro was granted Premio Montel, $4^{\text {th }}$ Edition by University of Foggia.

See online Appendix for additional materials.

Received for publication: 29 0ctober 2015.

Revision received: 11 February 2016.

Accepted for publication: 22 February 2016.

(C) Copyright M.A. Scaringelli et al., 2016

Licensee PAGEPress, Italy

Italian Journal of Agronomy 2016; $11: 716$

doi:10.4081/ija.2016.716

This article is distributed under the terms of the Creative Commons Attribution Noncommercial License (by-nc 4.0) which permits any noncommercial use, distribution, and reproduction in any medium, provided the original author(s) and source are credited. (strength, durability, mechanical harvesting, transparency, etc.) are identified.

\section{Introduction}

The use of plastic mulch in agriculture has progressively expanded in many countries over the years. The spread of mulching is due to agronomic benefits such as increases in soil temperature, reduced weed pressure, moisture conservation, reduction of certain insect pests, higher crop yields and more efficient use of soil nutrients. Furthermore, the economic benefits in terms of reduced costs resulting from water savings and reduced use of synthetic chemicals such as pesticides or herbicides, encourage the adoption of this farming technique.

Mulching of vegetable and fruit crops is being widely practiced since the beginning of the 1970s. Currently, plastic is used in any climate, soil or season for cultivating peanut, corn, cotton, vegetables and fruits (Kasirajan and Ngouajio, 2012). Today, fresh market producers mostly grown on plastic mulch include tomato, bell pepper, muskmelon, eggplant, slicing cucumber, watermelon (Ngouajio et al., 2008).

On the other hand, the widespread use of plastic mulching materials, especially black polyethylene, has caused a dramatic increase in environmental problems and human health risks in the world. These films are currently produced from petroleum-based plastics, usually polyethylene, and cause a considerable waste disposal problem. They are non-compostable and biodegradable only over a long period of time and thus can pollute the environment for periods greatly exceeding crop duration. Although there are no data reporting the use of mulching films, agriculture in general generates about 0.4-0.6 million tonnes (Mt) of plastic waste per year in the European Union (EU). The most significant sources of plastic waste are: pipes and fittings $(0.2$ $\mathrm{Mt}$ ); agricultural packaging (bags, liners and containers) collectively accounting for $0.079 \mathrm{Mt}$. In 2008, $1.243 \mathrm{Mt}$ of agricultural plastic waste was generated in the European Union of 27 Member States (EU-27), plus Norway and Switserland. Of this total amount, 53.6\% was disposed of and $46.4 \%$ was recovered (European Commission, 2011). The plastic waste is disposed of through landfills, incineration and recycling. The removal of the plastic is time consuming (about $16 \mathrm{~h}$ per hectare) and, despite the use of machines, it still requires hand labour. Moreover, because of high transportation costs and landfill tipping fees, farmers consider onsite burning to be economically more favourable (McCraw and Motes, 1991; Kasirajan and Ngouajio, 2012).

Considering that the on-field open burning of plastics in agriculture is illegal, the adoption of compostable products may represent an important opportunity to increase the environmental sustainability of the agricultural sector. 
Mulch films made from organic materials have already been on the market for several years, including films derived from modified starch (Mater-Bi ${ }^{\circledR}$, Biofilm ${ }^{\circledR}$; Novamont S.p.A., Novara, Italy), polylactic acid (Bioflex $^{\circledR}$; KERAKOLL S.p.A., Sassuolo, MO, Italy) or cellulose (Mimgreen Paper ${ }^{\circledR}$; MimGroup, Manlleu, Barcelona, Spain); additionally, there have been several attempts to develop other types of environmentally sustainable material to replace pollutant plastic mulches, such as crop residues, organic or paper mulches.

The main advantage of these biodegradable films derived from organic substances refers to the chance to directly integrate them into the soil at the end of their life. In this way, bacterial flora will transform these materials into carbon dioxide or methane, water and biomass, thus resulting in lower overall polluting impact. Indeed, from the economic point of view, the use of biodegradable materials allow to reduce the cost of labour, which is not needed for the film removal.

A number of studies have recently analysed the agronomic and environmental performance of paper mulch (Martin-Closas et al., 2003; Moreno et al., 2013; Haapala et al., 2014), polyethylene with additives for degradation or biodegradable films (Filippi et al., 2011; Saraiva et al., 2012; Benincasa et al., 2014). By conducting field experiments, these studies showed that these potential substitutes of conventional films offer the advantage of degrading into non-toxic components. Kasirajan and Ngouajio (2012) found that, despite multiple benefits, removal and disposal of conventional polyethylene mulches remain a major agronomic, economic and environmental constraint; the adoption of new biodegradable mulch films is still restrained because they are more expensive and their breakdown is generally premature in the field. Currently, since there is not an equivalent biodegradable alternative yet, the use of polyethylene mulching is even allowed in organic production in Europe by the Council Regulation No. 2092/91 (European Commission, 1991).

The ongoing research is moving toward the usability of the organic fraction from municipal waste in order to produce biodegradable materials. For instance, research carried out at the University of Torino over the last 7 years, has shown that urban and agriculture wastes are sources of soluble bio-based substances (SBOs). Plastic materials containing SBOs are particularly suitable for the manufacture of films for agricultural soil mulching (Montoneri et al., 2011; Franzoso et al., 2015).

Although the allocation of mulching films from SBOs is attractive for both commercial and sustainability issues, its market potential is still unknown. It is estimated that the global market of bio-plastics will grow at a rate of $20 \%$ per year (European Commission, 2011). However, although the demand for bio-plastics is expected to grow fast, there is a lack of study focusing on the farmers' acceptance, attitudes and preferences towards the use of such materials.

Numerous field experiments have been carried out on films of different colours and materials over the years (Cirujeda et al., 2012; Saraiva et al., 2012; Moreno et al., 2013), focusing on the development of materials and technologies to improve mechanical properties as well as biodegradability rate and environmental compatibility of mulching films. However, research has neglected the economic issues and the behavioural aspects of the adopters. The potential market of alternative bio-plastic products has been poorly reported in the literature, although ex-ante assessment is essential for investors and companies to make a reliable projection of the business opportunities. Moreover, the analysis of farmers' preferences for biodegradable mulching films regarding some intrinsic attributes, such as strength, durability or transparency, could lead manufacturers to improve the market products.

In light of this, a first objective of this work was to reveal the attitudes of farmers towards the adoption of biodegradable mulching films produced from organic wastes, in order to quantify the market acceptance of such products. Moreover, since their origin can be considered controversial, a second aim of the study was to explore whether there is a prejudice towards materials derived from organic wastes. Two wide effects related to the origin of materials were assumed, namely: i) there would be a reduced number of alternative adopters; ii) their willingness to pay will be lower than that for other currently available products. An experimental auction through a survey was used in order to assess farmers' willingness to pay for the new products. As described in section two, the survey was conducted in 2014 in the province of Foggia (Southern Italy) and involved a random sample of 107 horticultural farms. Although the randomness and the sample size do not allow extending the results of the survey to all the agricultural enterprises, at this stage, the study aimed to provide first indications of farmers' behaviour towards films from SBOs on a statistical basis. These aspects are presented in the section three. The discussions are presented in the fourth section. Finally, in the fifth section we have provided the conclusions.

\section{Materials and methods}

\section{Description of study area}

The geographic field of application for our research was the Province of Foggia (Apulia Region, Italy). The interest in this area lied in the fact that the province of Foggia is one of five areas in Italy with the highest rate of pollution resulting from the incineration of agricultural waste. In 2010, this area issued 10,254 megagram $(\mathrm{Mg})$ of carbon monoxide (CO), $473 \mathrm{Mg}$ of nitrogen oxides $\left(\mathrm{NO}_{\mathrm{x}}\right)$ and $488 \mathrm{Mg}$ of methane $\left(\mathrm{CH}_{4}\right)$ (ISPRA, 2013). The Province of Foggia extends for 6966.17 square kilometres with a population of 638,041 inhabitants; it is the second largest province in Italy in terms of cultivated area.

According to the Organisation for Economic Co-operation and Development's methodology (based on the parameter of the density of the population), the Province of Foggia is classified as predominantly rural. Furthermore, this area is divided into five macro homogeneous zones: an urban centre that coincides with the capital town, two lowlying rural areas with specialised intensive agriculture (Alto and Basso Tavoliere), and two rural areas with development problems (Subappennino Dauno and Gargano) characterised by medium mountains. Regarding the economic context, agriculture plays a prominent role in the local economy: the agricultural firms prevail compared to the industrial and other sectors. Foggia Province is one of the most extended agricultural areas in Italy, with 495,111.10 hectares of utilised agricultural area (UAA) (3.9\% of the national UAA) and with 48,149 firms (3\% of the national total) (Table 1).

The legal status is mostly represented by individual ownership with

Table 1. Farms size and crop typology for Foggia province.

\begin{tabular}{lcc} 
& UAA (ha) & Farms \\
Foggia & $495,111(100 \%)$ & $48,149(100 \%)$ \\
Vegetable crops* & $33,622(7 \%)$ & $3843(8 \%)$ \\
\hline Vegetable in open fields** & $33,231(7 \%)$ & $3791(8 \%)$ \\
Fresh tomatoes & $494.04(0.4 \%)$ & $168(0 \%)$ \\
\hline Processed tomatoes & $19,143(4 \%)$ & $1901(4 \%)$ \\
Other vegetables & $11,343(2 \%)$ & $1893(4 \%)$ \\
\hline
\end{tabular}

UAA, utilised agricultural area. *Vegetable crops include both the total of vegetables in open fields and protected vegetables; ${ }^{* *}$ Vegetables in open fields include the sum of fresh and processed tomatoes and other vegetables in market gardens. 
$98.4 \%$ of total enterprises accounting for $90.9 \%$ of the UAA. The land is clearly intended for crops (99.9\% of the total companies) (ISTAT, 2010). Looking at the data collected by national census (ISTAT, 2010), winter cereals are widespread, with 23,775 farms and 254,693.74 UAA. On the other hand, in recent years the provincial horticultural productions have been developing in a similar shape. Indeed, the most significant data refer to processed tomato crops, with 4\% of the total UAA and 1901 farms, summing up about 19,140 hectares, which confirms Foggia province leadership at the national level. Table 1 shows the data of the horticultural crops that would be suitable for the technique of mulching: 3843 farms growing vegetables over 33,622.95 hectares, almost the whole represented by open-field vegetables.

Table 2 reports classes of farmers' age and their educational level. Basically, the largest class covers farmers of 50 to 64 years old $(17,151)$, mostly having got primary or secondary educational level. As a whole, about $70 \%$ of farmers are older than 50 years and have at the most a secondary education level. Among specialists in horticulture, farmers' age shows a slightly different pattern, with a larger percentage of younger farmers ( $<=40$ years).

\section{Description of mulching technique in the case study area}

In modern crop production several materials may be used for mulching. In order to analyse the diffusion of mulching technique in the Province of Foggia, we needed to observe qualitative and quantitative data related to the number of films' adopters, the kind and the quantity of mulching materials used (e.g., application rate), the price of the mulch, the costs for mulching installation and labour needed for removing films, as well as specific incentives within the rural development plan (RDP) promoting the use of mulching films.

Basically, there are no official statistics about the diffusion and adoption of mulching technique at either a national or local level. Therefore, the first step of data gathering was based on direct interviews with local experts (e.g., agronomists, members of farmers' unions, technicians of extension services, individual farmers) as well as retailers and wholesalers about relevant characteristics of the mulching films, with a special focus on the intrinsic attributes influencing farmers' choices. Other relevant aspects refer to market prices of already-available mulching films. Moreover, during the interviews an in-depth description of mulching technique as applied in the research area was conducted. In detail, the technique of mulching is used for about 6-7 months, mainly during the spring and summer periods, for fresh market vegetables such as tomato, pepper, eggplant and melon.

The application rate $(\mathrm{kg} / \mathrm{ha})$ and the costs of the films $(€ / \mathrm{kg})$ used vary depending on several features such as the typology (i.e., biodegradable or not), the thickness of materials and their colour.

According to the local experts in the study area, for conventional films in polyethylene, $35 \mu \mathrm{m}$ is the optimal thickness, with about 450 $\mathrm{kg} / \mathrm{ha}$ being the application rate. At a market price of $2.55 € / \mathrm{kg}$, the conventional material costs $1150 € / \mathrm{ha}$. Conversely, biodegradable cellulose cornstarch (Mater-Bi ${ }^{\circledR}$, Novamont S.p.A.) has an application rate of about $180 \mathrm{~kg} / \mathrm{ha}(15 \mu \mathrm{m}$ thick) and a commercial price of $6 € / \mathrm{kg}$ : the total expenditure thus amounts to $1080 € /$ ha.

In the case of the adoption of the biodegradable films, the use of materials with low environmental impact is one of the actions financed by the operative plan. [The national schemes for the management of operational funds and operational programmes of producer organisations of fruits and vegetables (Council Regulation No. 1234/2007 - fruit and vegetables sector) cover material and deposition costs (European Commission, 2007). The only admissible expenses are the ones incurred for mulching through the use of materials conforming to the standard UNI EN 13655 and 14995 (biodegradable materials) (UNI, $2003,2007)$. The costs incurred on the same grounds for a repeated crop are eligible. The corresponding expenditure ceiling, expressed in $€ / \mathrm{m}^{2}$, is $0.15 € / \mathrm{m}^{2}$ plus $0.10 € / \mathrm{kg}$ if the resulting material is sent to a recovery centre and recycled.]. From the interviews with dealers and representatives of associations, we collected basic information relating to the materials' properties. In particular, some mechanical and optical characteristics were identified, such as the film resistance to various types of stress (tensile, tear and impact), the phenomenon of aging, the deterioration of the film due to sunlight and warmth of film (greenhouse effect) and the durability (mostly due to cycles of UV radiation, condensation and various weather phenomena). In choosing the type of material, it is also important to consider removal procedures (manual or mechanical) and disposal of the film. Among these attributes, five key aspects have been selected, which are considered crucial to farmers' decision to purchase agricultural mulch films, as reported in the next section.

\section{Sample and survey description}

The survey was carried out in May 2014 and the final sample included 107 farms located in the province of Foggia. Specialist horticulture farms were the targets of the survey. With the aim of gathering as much as possible a representative sample, some features such as farm size,

Table 2. Specialists in outdoor horticulture by age of the farm head.

\begin{tabular}{lcc} 
& Foggia & Percentage of the total horticulture \\
Age groups (\%) & & \\
$<35$ years & $2467(5 \%)$ & $25(12 \%)$ \\
35-49 years & $11,635(24 \%)$ & $70(33 \%)$ \\
$50-64$ years & $17,151(36 \%)$ & $81(39 \%)$ \\
$>=65$ years & $16,946(35 \%)$ & $34(16 \%)$ \\
Total & $48,199(100 \%)$ & $210(100 \%)$ \\
Education & & $11(5 \%)$ \\
PhD, degree, professional master & $3512(7 \%)$ & $45(21 \%)$ \\
Upper secondary education(high school) & $9541(20 \%)$ & $80(38 \%)$ \\
Secondary education (primary school) & $16,156(34 \%)$ & $67(32 \%)$ \\
Primary education (elementary school) & $16,389(34 \%)$ & $7(3 \%)$ \\
None & $2601(5 \%)$ & $210(100 \%)$ \\
Total & $48,199(100 \%)$ & \\
\hline
\end{tabular}

Source: ISTAT, 2010. 
crop pattern, farm location and farmers' age were used in the sampling procedure. Moreover, the sample involved farmers who already applied a mulching technique, whether biodegradable or conventional, as well as those farmers who currently did not apply one. The sample survey was carried out by face-to-face interviews based on a structured questionnaire of four sections. The first section intends to collected information related to farmers' socioeconomic characteristics such as farms' features (e.g., legal status, management type, land tenure, number of workers and type of crops), environmental concerns, risk propensity, social networks and information channels. The collection of this data was required to examine farmers' behaviour and their attitudes towards agricultural innovations (Birol et al., 2007; Prokopy et al., 2008; Bakopoulou et al., 2010; Blazy et al., 2011; Lin and Huang, 2012). The second section was directed at informing respondents about potential economic and environmental benefits of biodegradable films and at grasping farmers' attitudes with respect to their use. An initial request, like Have you ever utilised or are you using mulch films? (Question 24), allowed us to distinguish between users of a mulching technique and potential adopters. Then, the potential adopters were asked their general willingness to adopt a mulching technique (Question 25), followed by their willingness to specifically adopt biodegradable films (Question 32 ). At the same time, from those who already adopted mulch films (biodegradable or not), in-depth information about the application rate, colour, market price of used films and the current procedure for their disposal was obtained. Finally, all current users and all respondents who were willing to adopt biodegradable films were asked their preferences towards organic-waste-derived films (Question 34). For the questionnaire structure see Appendix Figure 1.

The third section focussed on farmers' preferences for films' properties (hereafter attributes) and their willingness to pay for them. In the first question farmers were asked to sort the following characteristics of agricultural films, the list of which was proposed randomly: strength (mechanical resistance during the stretch out of the film in the field), durability (compared to the crop duration), mechanical harvesting (possibility for mechanical harvesting of crops), transparency and disposal (minor operations for the removal and disposal of the film at the end of the farming cycle). Farmers ranked the abovementioned attributes using a five-point Likert scale according to their personal experiences and points of view.

After detecting farmers' preferences for films' properties, an auction simulation was carried out with the aim of assessing farmers' willingness to pay. We started with a first offer based on the current price of biodegradable films already available on the market and proceeded by asking if they were willing to spend more for the waste-based films with the characteristics desired, by means of two additional $10 \%$ price bids. For those who were willing to pay more, the highest price was directly asked. Similarly, if the respondent rejected the first offer, a downward price pattern was presented, with two different price bids of $10 \%$ and $20 \%$ lower. Finally, those who would pay even less were asked to express the minimum price at which they would purchase the product. A minor willingness to pay makes sense with respect to the origin of the raw material of the product. An example of the auction and the bids are shown in the Appendix.

The questionnaire ended with some minor personal information.

Table 3 reports the main features of the sample in terms of mulched area according to each crop. The crop with the largest mulched area is processed tomato, with 1290.5 ha, which in turn amounts to $58 \%$ of the total tomato area. More than half of specialist farms in processed tomatoes apply a mulching technique. On the other hand, crops such as melon, pepper, eggplant and fresh tomato are grown almost entirely by the mulching technique ( $90 \%$ of crop area). Watermelon has the largest percentage of the farms adopting mulches (89\% of total) followed by pepper (75\%) and fresh tomatoes (73\%). The lowest share (25\%) is found for potato.

\section{Results}

The number of potential adopters of the mulching technique and biodegradable films from SB0s is reported in Table 4. After informing respondents about some advantages of the mulching technique, $48.57 \%$ of the interviewees who do not use any materials for soil covering were willing to adopt mulches. Moreover, 35 out of 56 respondents would be in favour of using biodegradable materials after they were made aware of the fact that these products do not require removal and disposal procedures and that they allow for the mechanical harvesting of some crops such as tomatoes. [Among the most important advantages we mentioned were intensification of production, defence of the plantations from weeds, weather or conservation of temperature and soil moisture and other benefits.]. Finally, regarding the willingness to adopt biodegradable films from organic wastes, $94.12 \%$ of the respondents (summing the new adopters, conventional adopters and biodegradable adopters) were favourable to the use of these innovative materials, without showing any prejudice. According to this first result, the adoption of a mulching film does not depend on the nature of the raw materials used.

Table 3. Key features of the sample ( $n=107)$.

\begin{tabular}{|c|c|c|c|c|c|c|}
\hline Crops & $\begin{array}{c}\text { Total area } \\
\text { (ha) }\end{array}$ & $\begin{array}{l}\text { Mulching area } \\
\text { (ha) }\end{array}$ & $\begin{array}{l}\% \text { of hectares } \\
\text { with mulches }\end{array}$ & Total farms & $\begin{array}{c}\text { Farms adopting } \\
\text { mulches }\end{array}$ & $\begin{array}{c}\% \text { farms with } \\
\text { mulches }\end{array}$ \\
\hline Processed tomatoes & 1821.1 & 1290.5 & 71 & 93 & 56 & 60 \\
\hline Watermelon & 204.9 & 201.3 & 98 & 28 & 25 & 89 \\
\hline Pepper & 61.5 & 58.8 & 96 & 16 & 12 & 75 \\
\hline Zucchini & 26 & 17.8 & 68 & 10 & 4 & 40 \\
\hline Fresh tomatoes & 16.6 & 15 & 90 & 11 & 8 & 73 \\
\hline Eggplant & 12 & 11.3 & 94 & 7 & 4 & 57 \\
\hline Potato & 14.5 & 8 & 55 & 4 & 1 & 25 \\
\hline Other & 5 & 0 & 0 & 1 & 0 & 0 \\
\hline
\end{tabular}


The fourth column of Table 4 reports the motivations of the mulching non-adoption choice. The first reason for not adopting a mulching technique at all (row one) is the expensive costs. Indeed, 12 out 18 respondents would not apply mulches because of high purchase and installation costs. Secondly, farmers would not apply mulches because of impediments to mechanical harvesting. Regarding the motivations against the biodegradable films (row two), we found that many farmers did not trust the agronomic performance of these films (nine respondents) while another large group (eight respondents) complained about the rapid degradation of biodegradable films.

Finally, all of those who would not apply biodegradable films from organic waste (row three) declared they were doubtful of their environmental and agronomic performance.

Table 5 reports farmers' intentions for the adoption of SBO-based films according to his/her age and education level. As expected, in line with the wide recognised literature focusing on the diffusion of innovation, the frequency of adoption was relatively higher among younger and more highly educated farmers.

Table 6 shows a summary of willingness to pay (WTP) for wastebased biodegradable films, as well as of current average costs and application rates of films used. The WTP information was derived from the farmers willing to adopt the new mulch films (62 valid observations), while cost and application rate information was gathered only from those who already applied mulches. However, 13 of these respondents did not know the costs, while 11 did not remember the amount of the materials used. Costs and application rate are reported according to the film's typology. Since conventional plastic films have a greater thickness than biodegradable ones ( $35 \mu \mathrm{m}$ compared to $15 \mu \mathrm{m}$ ), the conventional adopters use, on average, more material in terms of weight per hectare $(188.03 \mathrm{~kg} / \mathrm{ha})$, with an average cost of $415.17 € / \mathrm{ha}$. The biodegradable users, instead, pay on average $420.95 € /$ ha, with $109.75 \mathrm{~kg} /$ ha being the average application rate. Some farmers use both conventional and biodegradable films, with an average price ranging between the aforementioned values. A second result of our research shows the willingness to pay for films containing SB0s: WTP ranges from a minimum value of 200 ( $€ / \mathrm{ha})$ to the maximum of $750(€ / \mathrm{ha})$, with a mean of $464.11(€ / \mathrm{ha})$. All three groups have expressed their willingness to pay for the SB0-based films at a higher price than the products already available on the market.

Table 7 reports the results of farmers' preferences for the films' attributes, such as strength, durability, mechanical harvesting, transparency and disposal, as well as the WTP for each feature. We can observe that the most crucial technical feature for the choice of a film is the high operational timeframe (3-6 months), followed by the strength of materials and compatibility with harvesting machinery. Indeed, 27 respondents out of 62 believed that the durability of the films for the whole crop cycle was an essential property. The strength during the stretch out of the film on the field was also very important, with 19 preferences expressed. On the other hand, there are properties without any importance such as transparency or ease in end-life disposal.

Table 4. Number of potential adopters (sample, $n=107)$.

\begin{tabular}{|c|c|c|c|}
\hline Willingness to adopt & $\begin{array}{l}\text { Number and percentage } \\
\text { of potential adopters }\end{array}$ & $\begin{array}{l}\text { Number and percentage } \\
\text { of non-adopters }\end{array}$ & $\begin{array}{l}\text { Motivation for not } \\
\text { adopting } \\
\text { (number of observations) }\end{array}$ \\
\hline $\begin{array}{l}\text { 1. Mulching technique } \\
\text { (new adopters) }\end{array}$ & $\begin{array}{l}17 \text { (48.57\%) out of } 35 \\
\text { (the interviewees who do not apply mulches) }\end{array}$ & $18(51.43 \%)$ & $\begin{array}{l}\text { High cost of purchase and installation (12) } \\
\text { No simple mechanical harvesting (5) } \\
\text { No adaptability to different types of soil (1) }\end{array}$ \\
\hline 2. Biodegradable films & $\begin{array}{l}35(62.50 \%) \text { out of } 56 \\
\text { (new adopters + conventional adopters) }\end{array}$ & $21(39.30 \%)$ & $\begin{array}{l}\text { Excessive soil preparation practices (2) } \\
\text { Rapid degradation (8) } \\
\text { Thinner than the conventional films (1) } \\
\text { High price (2) } \\
\text { Doubts about the agronomic performance (8) }\end{array}$ \\
\hline $\begin{array}{l}\text { 3. Biodegradable films } \\
\text { from organic waste }\end{array}$ & $\begin{array}{l}64(94.12 \%) \text { out of } 68 \\
\text { (new adopters }+ \\
\text { conventional adopters }+ \\
\text { biodegradable adopters) }\end{array}$ & $4(5.88 \%)$ & $\begin{array}{l}\text { Doubts about the environmental and agronomic } \\
\text { performance (moisture, duration, pollutants, etc.) (4) }\end{array}$ \\
\hline
\end{tabular}

Table 5. Farmers' adoption behaviour towards the soluble bio-based substances-based films (number of farmers) (sample, $\mathbf{n}=107)$.

\begin{tabular}{lcc} 
& Bodegradable films from organic waste & \\
Farmers' age & & 88 \\
$<35$ years & 14 & 61 \\
$35-49$ years & 25 & 49 \\
$50-64$ years & 22 & 60 \\
$>=65$ years & 3 & 60 \\
Total & 64 & 80 \\
Farmers' education & 8 & 59 \\
PhD, Degree, Professionalising Master & 27 & 60 \\
Upper secondary education (high school) & 26 & 38 \\
Secondary education (primary school) & 3 & 60 \\
None, Primary education (elementary school) & 64 & \\
Total & & \\
\hline
\end{tabular}


Table 8 reports the summary statistics for WTP by type of adopters (the adopters of the conventional films in polyethylene, the adopters of the biodegradable films in cornstarch and the adopters of both of them).

In particular, Table 8 shows the results obtained from auction. Approximately, within the sampled farmers, there were no significant differences in the WTP between new adopters and biodegradable users (respectively, 12 and 32 responses). By contrast, the WTPs expressed by the adopters of conventional films (20 responses) for films made from SB0s were significantly higher compared to other groups (503.5€/ha).
Moreover, farmers were divided on the basis of whether they were engaged or not in an operational plan, which covered half of the cost of mulches. The results show that the WTP was significantly higher for those farmers without operational plans for the use of mulching film. Finally, there was no significant difference among those who knew the cost of mulches and those who did not. For each attribute, the frequency (as a percentage of totals) and the average value of WTP distinguishing the three types of adopters are shown in Table 9.

With regard to the first group (conventional adopters), $45 \%$ of respondents expressed the most significant result, i.e., that durability

Table 6. Willingness to pay (€/ha) for waste-based mulches, current cost and application rate.

\begin{tabular}{|c|c|c|c|c|c|c|}
\hline Variable & & Number of observations (\%) & Mean & Std. Dev. & Min & $\operatorname{Max}$ \\
\hline \multirow{4}{*}{ WTP (€/ha) } & Sample & $62(100 \%) *$ & 464.11 & 101.30 & 200 & 750 \\
\hline & Conventional & $20(32 \%)$ & 503.50 & 114.96 & 200 & 750 \\
\hline & Biodegradable & $21(34 \%)$ & 440.71 & 75.66 & 300 & 540 \\
\hline & Both films & $9(15 \%)$ & 472.77 & 105.00 & 360 & 700 \\
\hline \multirow[t]{4}{*}{ Cost (€/ha) } & Sample & $59(100 \%)$ & 415.00 & 114.22 & 220 & 700 \\
\hline & Conventional & $30(51 \%)$ & 415.17 & 110.36 & 220 & 600 \\
\hline & Biodegradable & $21(36 \%)$ & 420.95 & 90.38 & 300 & 600 \\
\hline & Both films & $8(14 \%)$ & 398.75 & 184.11 & 220 & 700 \\
\hline \multirow[t]{4}{*}{ Application rate $(\mathrm{kg} / \mathrm{ha})$} & Sample & $61(100 \%)$ & 155.16 & 54.558 & 100 & 300 \\
\hline & Conventional & $33(54 \%)$ & 188.03 & 53.73 & 100 & 300 \\
\hline & Biodegradable & $20(33 \%)$ & 109.75 & 7.86 & 100 & 120 \\
\hline & Both films & $8(13 \%)$ & 133.12 & 24.63 & 105 & 170 \\
\hline
\end{tabular}

WTP, willingness to pay; Std. Dev., standard deviation. *The sample includes the respondents that were willing to adopt films from soluble bio-based substances but did not use a mulching technique; this is why it is different from the sum of conventional, biodegradable and both films users.

Table 7. Frequency of farmer's preferences for film properties $(n=62)$.

\begin{tabular}{|c|c|c|c|c|c|c|c|}
\hline Film's property & 1 Essential & 2 Very important & 3 Important & 4 Less important & 5 Not important & Other & $\begin{array}{c}\text { WTP } \\
\text { (€/ha mean) }\end{array}$ \\
\hline Strength & $14(23 \%)$ & $19(31 \%)$ & $17(27 \%)$ & $7(11 \%)$ & $4(6 \%)$ & $1(2 \%)$ & 458.34 \\
\hline Durability & $27(44 \%)$ & $14(23 \%)$ & $12(19 \%)$ & $9(15 \%)$ & $0(0 \%)$ & $0(0 \%)$ & 452.22 \\
\hline Mechanical harvesting & $11(18 \%)$ & $14(23 \%)$ & $15(24 \%)$ & $12(19 \%)$ & $10(16 \%)$ & $0(0 \%)$ & 463.87 \\
\hline Transparency & $3(5 \%)$ & $8(13 \%)$ & $4(6 \%)$ & $13(21 \%)$ & $34(55 \%)$ & $0(0 \%)$ & 469.49 \\
\hline Disposal & $6(10 \%)$ & $6(10 \%)$ & $14(23 \%)$ & $21(34 \%)$ & $14(23 \%)$ & $1(2 \%)$ & 468.19 \\
\hline
\end{tabular}

WTP, willingness to pay.

Table 8. Differences in willingness to pay among subgroups $(\mathrm{n}=62)$.

\begin{tabular}{|c|c|c|c|c|c|}
\hline WTP (€/ha) & Observations & Mean & Std. Dev. & Min & $\operatorname{Max}$ \\
\hline Willingness to adopt mulching technique (new adopters) & 12 & 432.92 & 103.23 & 250 & 600 \\
\hline Willingness to adopt biodegradable films & 32 & 484.69 & 106.65 & 200 & 750 \\
\hline Willingness to adopt biodegradable films from organic waste & 62 & 464.11 & 101.30 & 200 & 750 \\
\hline $\begin{array}{l}\text { Already applying mulching films } \\
\text { Conventional films } \\
\text { Biodegradable films } \\
\text { Both films }\end{array}$ & $\begin{array}{c}20 \\
21 \\
9\end{array}$ & $\begin{array}{c}503.5^{* *} \\
440.71 \\
472.78\end{array}$ & $\begin{array}{c}114.96 \\
75.67 \\
105.00\end{array}$ & $\begin{array}{l}200 \\
300 \\
360\end{array}$ & $\begin{array}{l}750 \\
540 \\
700\end{array}$ \\
\hline $\begin{array}{l}\text { Operational plan engagement } \\
\text { Yes } \\
\text { No }\end{array}$ & $\begin{array}{l}21 \\
27\end{array}$ & $\begin{array}{c}459.56 \\
481.30^{*}\end{array}$ & $\begin{array}{c}77.37 \\
118.91\end{array}$ & $\begin{array}{l}300 \\
200\end{array}$ & $\begin{array}{l}700 \\
750\end{array}$ \\
\hline $\begin{array}{l}\text { Knowledge of mulches cost } \\
\text { Yes } \\
\text { No }\end{array}$ & $\begin{array}{l}39 \\
23\end{array}$ & $\begin{array}{l}463.20 \\
465.65\end{array}$ & $\begin{array}{c}104.36 \\
98.17\end{array}$ & $\begin{array}{l}200 \\
250\end{array}$ & $\begin{array}{l}750 \\
700\end{array}$ \\
\hline
\end{tabular}

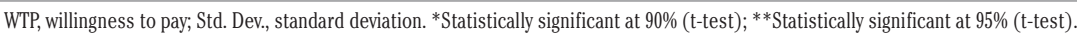


was an essential quality for which they would pay an average price of 485.45 (€/ha). Although a higher price (on average about $510 € / \mathrm{ha}$ ) was expressed for transparency, $55 \%$ of respondents considered this property the least important. The durability was essential for $67 \%$ of users of biodegradable films and strength was also very important (52\%). Again, transparency received marginal attention from the farmers.

\section{Discussion}

At the moment, biodegradable plastic represents just a tiny market compared with conventional petrochemical materials. Despite multiple benefits, the adoption of new biodegradable mulch films is restricted because they are more expensive and their breakdown is generally premature in the field (Kasirajan and Ngouajio, 2012). Although results of this research may be not representative of larger farming areas due to the limited sample, the respondent farmers' willingness to adopt biodegradable (SBO-based) films as well as their willingness to pay for them reveals a remarkable potential demand. Moreover, our findings show that actual expenditure declared by the respondents for biodegradable films was not much higher than for conventional, resulting in a similar amount. As a whole, although the application rate and the market price of the two films' typologies are different, we found a similar average expenditure for mulches. While the mentioned result may diverge from Kasirajan and Ngouajio (2012), in line with reports of these authors the premature breakdown in the field of biodegradable films was the most common farmer motivation for the rejection of these products.

Our findings show that the adoption of a mulching film does not depend on the nature of the raw material used. The absence of a negative bias by the adopters should lead investors to enter the market with these new products, contributing to the sustainability of farming activities and, at the same time, giving a green solution to the disposal of municipal wastes. Moreover, with extreme relevance for SBO-based products, farmers do not take transparency into account in their decisions. This result supports the efforts of other researches (e.g., Montoneri et al., 2011; Franzoso et al., 2015) aimed at finding out (marketable) SB0s from urban and agriculture wastes.

On the other hand, in this research farmers' preferences towards films' attributes, such as strength, durability, mechanical harvesting, transparency and disposal, were analysed. The results show that the most remarkable technical feature is the operational timeframe in relation to crop-wise duration. Moreover, the strength of materials and compatibility with harvesting machinery pay a relevant role in the farmers' decision process. The findings imply that for a larger diffusion of biodegradable films developers should pay attention to a film's durability and strength, with the chance to diversify market products according to the timeframe of each crop.

A final remark refers to the fact that farmers' willingness to adopt seems to apply the diffusion innovation theory (Rogers, 1995). Indeed, the younger the farmer the higher the frequency of adoption. Similar results can be observed for farmers' education. These findings - along with the fact that, on average, the monetary values expressed by the respondents (WTP) was at least not below the current market price of other materials - provide argument that adopting the process is not merely a monetary issue.

\section{Conclusions}

In recent decades, there has been an increased use of plastics in agriculture, often illegally disposed of by open on-field burning. At the same time, there is positional for biowaste to be chemically treated to obtain SBOs, which in turn might be used for several applications such as fertilisers or materials to create biodegradable plastic polymers. Therefore, the adoption of biodegradable products may represent an important opportunity to increase the environmental sustainability of the agricultural sector. Indeed, the use of biodegradable mulching films (in particular those according to UNI 11495/2013) is one of the volunteer activities implemented by the farm-

Table 9. Frequency of farmers' preferences and their willingness to pay by type of film adopted (n=62).

\begin{tabular}{|c|c|c|c|c|c|c|c|}
\hline Film's property & Essential & 2 Very important & 3 Important & 4 Less important & 5 Not important & Other & $\begin{array}{c}\text { WTP } \\
\text { (€/ha mean) }\end{array}$ \\
\hline \multicolumn{8}{|c|}{ Conventional adopters (20 respondents) } \\
\hline Strength & $5(25 \%)$ & $6(30 \%)$ & $7(35 \%)$ & $1(5 \%)$ & $0(0 \%)$ & $1(5 \%)$ & 507.13 \\
\hline Durability & $9(45 \%)$ & $3(15 \%)$ & $4(20 \%)$ & $4(20 \%)$ & $0(0 \%)$ & $0(0 \%)$ & 485.45 \\
\hline Mechanical harvesting & $3(15 \%)$ & $4(20 \%)$ & $5(25 \%)$ & $4(20 \%)$ & $4(20 \%)$ & $0(0 \%)$ & 506.50 \\
\hline Transparency & $1(5 \%)$ & $3(15 \%)$ & $0(0 \%)$ & $5(25 \%)$ & $11(55 \%)$ & $0(0 \%)$ & 510.20 \\
\hline Disposal & $2(10 \%)$ & $3(15 \%)$ & $4(20 \%)$ & $6(30 \%)$ & $5(25 \%)$ & $0(0 \%)$ & 504.07 \\
\hline \multicolumn{8}{|c|}{ Biodegradable adopters (21 respondents) } \\
\hline Strength & $5(24 \%)$ & $11(52 \%)$ & $4(19 \%)$ & $1(5 \%)$ & $0(0 \%)$ & $0(0 \%)$ & 400.93 \\
\hline Durability & $14(67 \%)$ & $4(19 \%)$ & $3(14 \%)$ & $0(0 \%)$ & $0(0 \%)$ & $0(0 \%)$ & 448.15 \\
\hline Mechanical harvesting & $1(5 \%)$ & $4(19 \%)$ & $7(33 \%)$ & $6(29 \%)$ & $3(14 \%)$ & $0(0 \%)$ & 447.54 \\
\hline Transparency & $1(5 \%)$ & $2(10 \%)$ & $2(10 \%)$ & $4(19 \%)$ & $12(57 \%)$ & $0(0 \%)$ & 439.00 \\
\hline Disposal & $0(0 \%)$ & $0(0 \%)$ & $5(24 \%)$ & $10(48 \%)$ & $6(29 \%)$ & $0(0 \%)$ & 442.83 \\
\hline \multicolumn{8}{|c|}{ Both adopters (9 respondents) } \\
\hline Strength & $0(0 \%)$ & $2(22 \%)$ & $2(22 \%)$ & $3(33 \%)$ & $2(22 \%)$ & $0(0 \%)$ & 471.88 \\
\hline Durability & $3(33 \%)$ & $2(22 \%)$ & $2(22 \%)$ & $2(22 \%)$ & $0(0 \%)$ & $0(0 \%)$ & 470.83 \\
\hline Mechanical harvesting & $2(22 \%)$ & $3(33 \%)$ & $2(22 \%)$ & $1(11 \%)$ & $1(11 \%)$ & $0(0 \%)$ & 464.50 \\
\hline Transparency & $0(0 \%)$ & $1(11 \%)$ & $2(22 \%)$ & $3(33 \%)$ & $3(33 \%)$ & $0(0 \%)$ & 468.96 \\
\hline Disposal & $3(33 \%)$ & $1(11 \%)$ & $1(11 \%)$ & $0(0 \%)$ & $3(33 \%)$ & $1(11)$ & 457.67 \\
\hline
\end{tabular}

WTP, willingness to pay. 
ers financed by the European Union under the RDP (UNI, 2013). For the 2014-2020 period, the Measure 10 - called Payment for agri-environment-climate commitments - is drawn as the line of action through which the European Union is preparing to compensate farmers for the increased costs and lost profits that may result from the adoption of voluntary and more sustainable production methods. In this direction, the allocation of SBOs in the agricultural market has a rather high and attractive potential, but the exact extent to which biodegradable plastics will replace traditional one is still not well known. This research attempted to evaluate the market potential of innovative biodegradable mulching films by estimating farmers' WTP. We proved that there is not a negative prejudice towards materials derived from organic waste. In addition, farmers' preferences towards mulching films' attributes were identified. Although the randomness and the sample size do not allow us to extend the results to the entire agricultural sector, these first findings seem quite encouraging. Indeed, there would be a market potential for these materials, but, however, one must take into account the decisive steps necessary to facilitate the complete replacement of traditional plastics. Among others, field-testing is necessary to demonstrate the mulches' agronomic as well as environmental performance. Finally, the preliminary results reported will require further study aimed at exploring the determinants of farmers' willingness to adopt and to pay for SBO-based films.

\section{References}

Bakopoulou S, Polyzos S, Kungolos A, 2010. Investigation of farmers' willingness to pay for using recycled water for irrigation in Thessaly region, Greece. Desalination 250:329-34.

Benincasa P, Massoli A, Polegri L, Concezzi L, Onofri A, Tein F, 2014. Optimising the use of plastic protective covers in field grown melon on a farm scale. Ital. J. Agron. 9:8-14.

Birol E, Koundouri P, Kountouris Y, 2007. Farmers' demand for recycled wastewater in Cyprus: a contingent valuation approach. Environmental Economy and Policy Research Discussion Paper Series, Department of Land Economics, University of Cambridge, UK.

Blazy JM, Carpentier A, Thomas A, 2011. The willingness to adopt agro-ecological innovations: application of choice modelling to Caribbean banana planters. Ecol. Econ. 72:140-50.

Cirujeda A, Aibar J, Anzalone A, Martín-Closas L, Meco R., Moreno MM, Pardo A, Pelacho AM, Rojo F, Royo-Esnal A, Suso ML, Zaragoza C, 2102. Biodegradable mulch instead of polyethylene for weed control of processing tomato production. Agron. Sustain. Dev. 32:889-97.

European Commission, 1991. Council Regulation (EEC) No 2092/91 of 24 June 1991 on organic production of agricultural products and indications referring thereto on agricultural products and foodstuffs. In: Official Journal, L 198, 22/7/1991, pp 1-15.

European Commission, 2007. Council Regulation (EC) No 1234/2007 of 22 October 2007 establishing a common organisation of agricultural markets and on specific provisions for certain agricultural products (Single CMO Regulation). In: Official Journal, L 299, 16/11/2007, pp 1-149.

European Commission, 2011. EU DG Environment. Plastic waste in the environment - Specific contract 07.0307/2009/545281/ETU/G2 under Framework contract ENV.G.4/FRA/2008/0112 - Revised final report; April 2011. Available from: http//ec.europa.eu/environment/ waste/studies /pdf/plastics.pdf

Filippi F, Magnani G, Guerrini S, Ranghino F, 2011. Agronomic evaluation of green biodegradable mulch on melon. Ital. J. Agron. 6:111-6.

Franzoso F, Tabasso S, Antonioli D, Montoneri E, Persico P, Laus M, Mendichi R, Negre M, 2015. Films Made from Poly (vinyl alcohol-co-ethylene) and Soluble Biopolymers Isolated from Municipal Bio waste. J. Appl. Polym. Sci. 132:1-11.

Haapala T, Palonen P, Korpela A, Ahokas A, 2014. Feasibility of paper mulches in crop production: a review. Agr. Food Sci. 23:60-79.

ISPRA (Istituto Superiore per la Protezione e la Ricerca Ambientale), 2013. Italian greenhouse gas inventory, 1990-2011 - National Inventory Report no. 177/2013. Available from: http//www.isprambiente.gov.it/files/pubblicazioni/rapporti/Rapporto_177_2013.pdf/view

ISTAT (Italian National Institute of Statistics), 2010. [6th general census of agriculture]. Available from: http:/censimentoagricoltura. istat.it/ index.php?id=73 [In Italian].

Kasirajan S, Ngouajio M, 2012. Polyethylene and biodegradable mulches for agricultural applications: a review. Agron Sustain Dev, 32:501-29.

Lin PC, Huang YH, 2012. The influence factors on choice behaviour regarding green products based on the theory of consumption values. J. Clean Prod. 22:11-8.

Martín-Closas L, Soler J, Pelacho AM, 2003. Effect of different biodegradable mulch materials on an organic tomato production system. In: Association for Technology and Structures in Agriculture - KTBL (Ed.), Biodegradable materials and natural fibre composites. KTBL, Darmstadt, Germany, pp 78-85.

McCraw D, Motes JE, 1991. Use of plastic mulch and row covers in vegetable production. Cooperative Extension Service, Oklahoma State University. OSU Extension Facts F-6034.

Montoneri E, Mainero D, Boffa V, Perrone DG, Montoneri C, 2011. Biochemenergy: a project to turn a urban wastes treatment plant into bio refinery for the production of energy, chemicals and consumer's products with friendly environmental impact. Int. J. Global Environ. 11:170-96.

Moreno MM, Moreno C, Tarquis AM, 2013. Mulch materials in processing tomato: a multivariate approach. Sci. Agric. 4:250-6.

Ngouajio M, Auras R, Fernandez RT, Rubino M, Counts JW, Kijchavengkul T, 2008. Field performance of aliphatic-aromatic copolyester biodegradable mulch films in a fresh market tomato production system. Horttechnol. 18:605-10.

Prokopy LS, Floress K, Klotthor-Weinkauf D, Baumgart-Getz A, 2008. Determinants of agricultural best management practice adoption: Evidence from the literature. J. Soil Water Conserv. 63:300-11.

Rogers E, 1995. Diffusion of innovations, 4th ed. The Free Press, New York, NY, USA.

Saraiva A, Costa R, Carvalho L, Duarte E, 2012. The use of biodegradable mulch films in muskmelon crop production. Basic Res. J. Agric. Sci. Rev. 1:89-95.

UNI (Ente Italiano di Normazione), 2003. UNI EN 13655:2003. Materie plastiche - Film termoplastici per pacciamatura per uso in agricoltura ed orticoltura; 01 maggio 2003. UNI, Milano-Roma, Italy.

UNI (Ente Italiano di Normazione), 2007. UNI EN 14995:2007. Materie plastiche - Valutazione della compostabilità - Schema di prova e specificazioni; 05 luglio 2007. UNI, Milano-Roma, Italy.

UNI (Ente Italiano di Normazione), 2013. UNI 11495:2013. Materiali termoplastici biodegradabili per uso in agricoltura e orticoltura - Film per pacciamatura - Requisiti e metodi di prova; 20 giugno 2013. UNI, MilanoRoma, Italy. 